\title{
Discussion of MICE Industry's Development and the Hainan urban economy Construction
}

\author{
Xueqiu Zhuang \\ Institute of tourism \\ Hainan Institute of Science \& Technology \\ Haikou,China \\ 274355812@qq.com
}

\author{
Yu Zhai \\ Institute of tourism \\ Hainan Institute of Science \& Technology \\ Haikou,China \\ zaiyuzaiyu@163.com
}

\begin{abstract}
Today's MICE industry with powerful ecnomy drives and influence to attract the attention and development from all over the world. Under the background of Great efforts to build international tourism island, Hainan possess some of the unique advantages with the development of MICE industry, but it still has some problems at the same time. How to solve these problems and make use of these advantages to develop and improve the level of MICE Industry in Hainan, and to make MICE industry in Hainan to become a powerful driving force in HaiNan economical development. To a certain extent, it reflects the development of city construction and the level of opening to the outside world of Hainan.
\end{abstract}

Keywords-MICE Industry; International tourism island; Advantage;Problem; City construction

\section{INTRODUCTION}

The MICE industry is know as" the 21 st century sunrise industry", it a comprehensive service industry which involves many aspects of economic development and can make 1:9 huge economical drawing function. The development of Mice Industry have high requirement on hardware and software throughout the MICE industry of a city. It needs developed economy, perfect infrastructure, assistant facilities and high level of service; or it needs highly international openness and relevance; or it needs in an advantageous geographic location and in the center of the trade and the captial flows.Hainan has the advantageous natural conditions in the development of MICE industry[1], we can hold exhibitions in any season, and the MICE indusry and tourism industry can help each other forward.

\section{ADVANTAGE}

\section{A. Natural conditions.}

The ambient air quality of the hole province is maintaining the first level, the surface water environment quality overall is good, the Forest coverage rate reached $60.5 \%$, The air quality index of Hainan province ranks the first in China, and Hainan is a natural oxygen bar. The average air quality index of cities in Hainan province in October 2015 are demonstrated in chart 1. Hainan has unnaturaland extraordinary advantage in Ecological
Development,health and vacationing industry exhibition tourism projects[2].

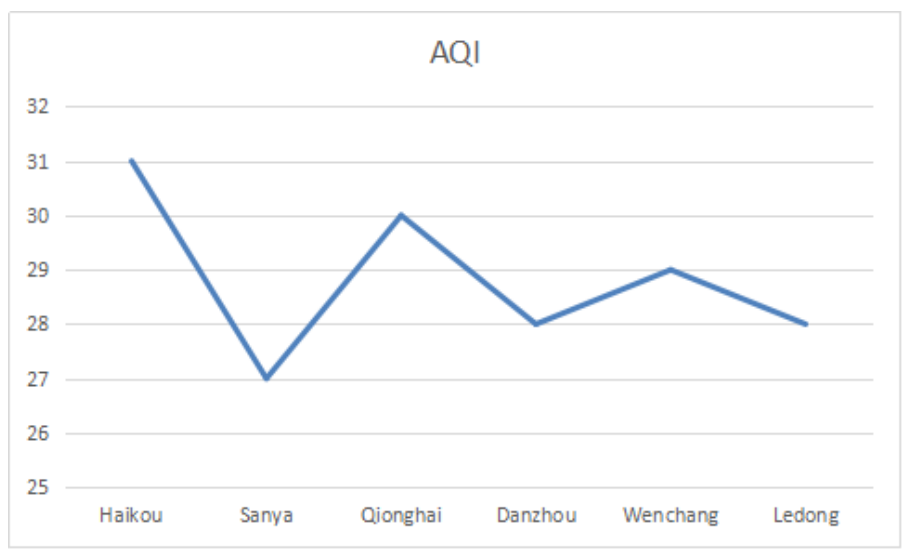

Figure 1. The average air quality index of cities in Hainan province in October 2015

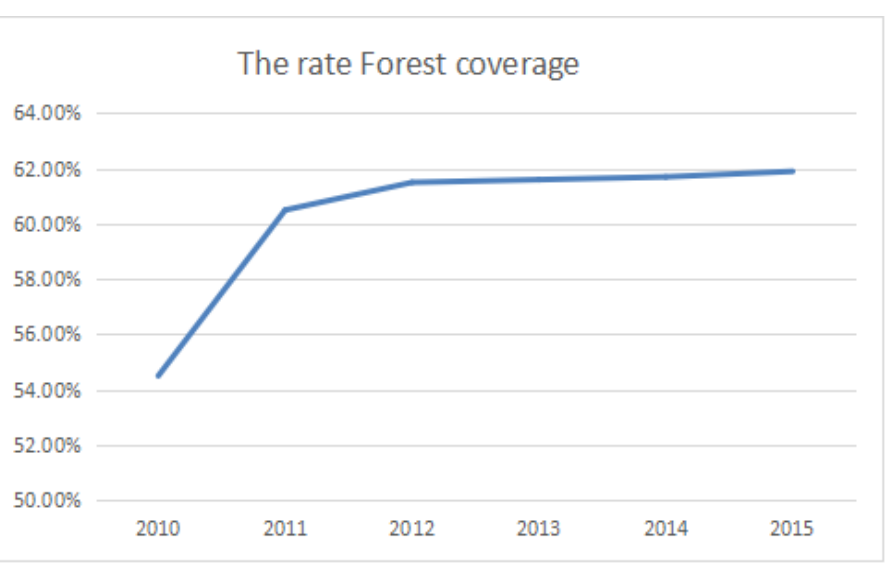

Figure 2. The forest coverage rate during the past five years

\section{B. Geographical advantage.}

From outside, Hainan adjacents to the economic developed regions such as Guangdong/HongKong/Macao and is located in a Marine traffic arteries connecting east and 
southeast Asia. From internal, Hainan have guangdonghainan railway, east-west line around island highway ,haikou meilan airport and sanya phoenix airport, which makes hainan has the convenient transportation network from inside and outside, and provides location advantage for exhibition activities[3].

\section{Infrastructure.}

Hainan' s hardware facilities is gradually perfected, the meeting venue quantity is gradually increased and expanded, Hainan has international conference exhibition center, sanya Asia Pacific international conference center, and numerous conference hotel, this will attract a large number of conference and exhibition to be hold in hainan. The number of tourists and five-star hotels in Hainan also increase each years, as you can see in Fig .3.It is worth mentioning that the international exhibition center which is haikou's significance landmark will be put into use in 2011,this makes hainan has a large conference exhibition venues, and the venues equipment achieves the international exhibition standards. In less than a year time[4], Here has held several large-scale exhibition and conference, and the center becomes the "support the tower" of haikou exhibition industry.

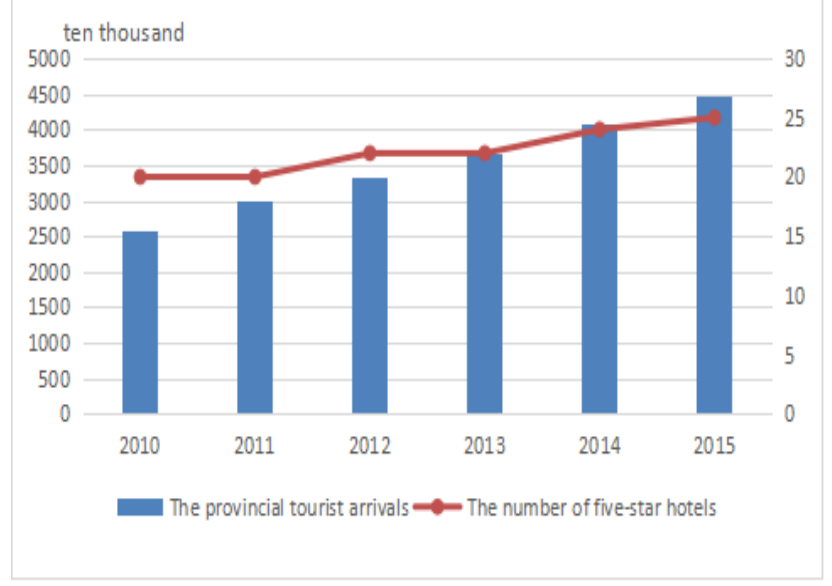

Figure 3. The number of visitors to Hainan island in the past five years and the number of five star hotels.

The exhibition environment continuously optimized. Hainan government proposed to speed up the development of MICE industry, and government has issued the trial measures for management of haikou exhibition organizers and the interim measures for the use and management of haikou exhibition industry development special funds, support the development of exhibition with special funds, the relevant departments are also trying to coordinate and carry out exhibition services well. And Pay attention to strengthen the guidance of MICE industry to exchange and cooperation with neighboring exhibition business [5].

\section{International tourism island strategy and Boao Forum corresponding brand's impact efficiency.}

When the construction of Hainan international tourism island rise to the national strategy, the MICE industry will get more and more attention. A group of international and national large exhibitions and Forums are held in Hainan, such as "China forest tourism expo", "The 11th world toilet summit and sanitary ware, sanitation equipment exhibition", the BRICS Summit etc bull session. Every year after October, all kinds of exhibition and annual meeting will be hold one by one. According to the statistics, in 2011 there are 61 commercial exhibitions and marches held in Haikou Exhibition Center, the usable floor area is 1.69 million square meters, the turnover is 54.1 billion yuan RMB. The WORLDEX GEC one of the largest exhibition company of Asia set up sino-foreign joint exhibition company in Haikou in 2011.

\section{THE EXISTENCE OF PROBLEM}

Although Hainan has the multiple advantages in exhibition industry development on the hardware aspects, but we still can't ignore that Hainan's MICE industry is small scale, slow development, relatively lags in the construction of venues, conference and exhibition center of facilities is not perfected, foundation is weak, and can't meet the multiple needs of exhibitors[6].

On the software environment,Hainan MICE industry as a whole is still in the primary stage of development at present, most of the exhibition enterprises lack of scientific development strategy and big exhibition experience. Relevant professional especially high-level personal gaps is large; The MICE industry market is lacked of brand concept.

\section{BASED ON THE CONSTRUCTION OF INTERNATIONAL TOURISM ISLAND, MICE INDUSTRY AND TOURISM INDUSTRY PROMOTES COMMON DEVELOPMENT}

\section{A. Improving the environment.}

From the development experience of German ,Singapore and other country who has world-famous exhibition destination, if Hainan wants to become a successful exhibition destination it requires three key elements:1) Having good exhibition industry infrastructure;2) Having perfect supporting facilities, convenient transportation, comfortable and convenient hotel and related supporting services;3) Having continuous investment.

\section{B. Gather Location distribution advantage.}

Thoughout the Advanced exhibition center city at home and abroad we can learn that every exhibition center city has its own exhibition features. Hainan MICE development in urban cities also need to be positioned according to the economic development characteristics of the exhibition and convention city development requirements. Hainan three exhibition center of city, Haikou, Hainan Boao, Sanya require organic combination complement each other. As the capital of Hainan Province, Haikou is the political, economic, cultural and transportation center, the exhibition industry development mainly based on the comprehensive exhibition, Boao with the "Boao Forum for Asia" influence is aimed at international markets to create "Asia Exhibiton Center ",Sanya is an international coastal tourist city focused on exhibition and tourism combined[7]. 


\section{Increasing the development of international sports market.}

Hainan has superior natural conditions and tourism growing international influence, a number of international sporting events and major events have chosen held in Hainan. For example, Miss World Trials, Central Hainan International Road Cycling Race, Central Hainan Island International Regatta, Hainan International Snooker Tournament, Sanya Open Beach Volleyball World Tour and golf tournament, etc. have been held in Hainan. According to Hainan currently features, the international market influence is larger than the domestic market, for the better development of exhibition industry, we need to pay more attention on the needs of the international market, with the international market influence to bring more domestic events to be held in Hainan.

\section{Government-led, promote the exhibition by meetings, promote by forums}

In recent years, Hainan MICE industry has gotten a certain development, particularly the completion of Hainan International Convention and Exhibition Centre, the MICE industry is booming momentum of development, and the MICE industry is in infancy state. Hainan MICE industry should be developed in the model of government-led, promoting by the exhibition and promoting by Forum, and foster festivals and international exhibition brands on this basis, promotes festivals with local characteristics and ethnic characteristics of folk actively, Innovating to have characteristics of Hainan Fun Festival and do well in Boao Forum for Asia and other high-end forum[8].

\section{E. The introduction of talent, the development of exhibition education.}

In order to improve the level of MICE industry, talent is the key. MICE industry needs introduction talent personnel of exhibition in time,make good job of MICE Education and Training. Government, MICE enterprises can introduce a number of experienced and strong theoretical knowledge of exhibition personnel first, increase MICE practitioners qualification training, use preferential policies to attract the high standard domestic and foreign companies to enter Hainan MICE market, lead and motivate companies to participate in along with the development of the exhibition industry in Hainan. Colleges and universities can establish exhibition management and other related specialties, to train a group of high starting point Exhibition professionals. Hainan major colleges and universities have not set up the exhibition management and other related specialties, talent development which is extremely lacking in the exhibition industry in Hainan side at present.

Further development of the city's MICE industry needs strong English penetration, Hainan as an international tourism island, construction in developing foreign language guides people is becoming more and more, but at present English penetration staff is unable to meet the development of the MICE industry in Hainan. So, the development of Hainan MICE industry needs to increase the penetration of English and convention staff at the same time, to grow and gain enough horsepower for Hainan MICE industry development[9]. MICE industry is a highly integrated industry, according to the status of MICE industry in Hainan,the development and growth needs to carried out multifaceted intervention on exhibition services and to create a momentum for the development of MICE industry.

Hainan international tourism island has brought a positive impact on Hainan MICE indusry development in many ways, and the successful development of MICE industry in Hainan can also affect the city's economic development, the impact of Hainan tourism development, the formation of MICE tourism.

V. THE DEVELOPMENT OF EXHIBITION INDUSTRY WILL BECOME A NEW ENGINE OF URBAN ECONOMIC DEVELOPMENT IN HAINAN

The MICE industry was known as: "City Bread", "urban economy booster," Someone once vividly commendable: if we held an inernational conference or MICE in a city,then the influence should be like a plane fly over the city with pouring money. From the witty phrase we are not difficult to find how improtant the development of MICE industry on urban development[10].

\section{A. A strong industrial driving force.}

One of the characteristic of exhibition industry is similar to tourism, is an industry with strong driving ability, may have a strong industrial driving effect of agglomeration and industry. It not only promote tourism, commerce, logistics, communications, catering, accommodation and other aspects, but also promote the further development of the regional industry gathering of the "power engine" and promote regional industrial brand value. Haikou, Boao, Hainan, Sanya will form the three pillars of the exhibition industry pattern, driven economic development in surrounding counties and cities along the coast of Hainan[11].

\section{B. High overall efficiency}

(1)Economic Benefits.The MICE industry has a low cost, high income, high profit advantage, can bring more than $20 \%-25 \%$ of economic profit for the host city, which is a key point to many cities who develop the MICE industry[12], this is also the force for rapid development of exhibition economy.

(2)Social benefits. MICE is an integrated service industry which gather business activity, information exchange, sightseeing, entertainment and leisure in one, a platform with new ideas, new concepts communication. Foreign cultures, ideas, technology, products can bring to the developing city of Revelation, can contact with the outside world closely, promote urban development, foster the city's unique charm and influence. The development of MICE industry had an impact in Hainan city construction. Some big conferences and exhibitions held in Hainan spread new international concept to Hainan citizen. Having a positive impact on Exhibition and cultural development[13].

(3)Environmental Benefits. The MICE industry is known as the "smokeless industry,", due to the pollution 
characteristics is conducive to environmental protection, which is according with sustainable development objectives.

\section{Help to enhance the overall image of Hainan International Tourism Island.}

Large-scale exhibition in enhancing the overall image of the city can produce three major effect.

(1)Promoting the municipal building In recent years, the municipal government of Hainan has built a large-scale convention and exhibition center, East Central Railway and other infrastructure, which promoted the renewal and construction of urban infrastructure, created conditions for the development of MICE industry in Hainan[14].

(2)Raising the city's reputation. MICE is selling product and technology, but convention city can also be used to operate and promote as a product. As we all know, Hainan is a tourist city and has a certain reputation at home and abroad. If Hainan can become a well-known convention city, then Hainan' s image and reputation will be further enhanced in the domestic and international.

(3)Provide employment opportunities. MICE industry is a service industry, we need the service personnel, and this can provide a lot of employment opportunities for Hainan.

\section{CONCLUSIONS}

Era in the development, Hainan will also be in rapid development with the great efforts to build an international tourist island. In the natural and man created conditions, Hainan's MICE industry will also usher in a period of rapid development.

\section{REFERENCES}

[1] LuoXia,Hainan MICE industry Occasion to seek development,Hainan Daily,2012-01-13.

[2] Xulingzhi,Outlet of exhibition industry development in Hainan[J],. Business Marketing,2008(11),86-92

[3] Jihongmei,Exhibition Industry to help the city take off,Ningbo Daily, 2006-11-20.

[4] Zhouzhiping, Catalyst for urban economic development[J],Management and Strategy 2008(8),103-106

[5] Jiang Ting,Mice tourism strategy research on hainan island [J].Science and technology information. 2011(2),pp.145-152

[6] Ke-jiang feng,Hong da xi,Exhibition talents training and exhibition economy research were reviewed [J].Journal of chongqing institute of technology: the social sciences. 2010( ),pp.167-169

[7] Wang Guikai,WeiMing,Hainan exhibition marketing strategy [J]. Cooperative economy and technology. 2012(4),pp.183-188

[8] Haiying-chen, Xiao-hong zeng,Hainan agricultural ecological tourism planning and development problem discussed in this paper [J].Tropical agricultural science. 2011(6),pp.195-200

[9] Cai Lan,The SWOT analysis and countermeasure research of exhibition industry development in hainan [J].The knowledge economy. 2011(7),pp.256-259

[10] Andreas Voellmy,Junchang Wang. Scalable software defined network controllers[J]. ACM SIGCOMM Computer Communication Review . 2012 (4),pp.169-174

[11] Liu Qianqian ,Jiang Jun,Hainan exhibition industry development condition analysis [J].The national business.2014(),pp.324-328

[12] GuanYuanYuan,Hainan international tourism island culture construction research, [Hainan normal university masters thesis].2013(),pp.267-275

[13] XinJianRong,Hainan international tourism island construction goal and the resources environment sustainable strategy [J].Haikou economy college journal.2010(),pp.289-294

[14] Liu-qin Chen,Exhibition economy and urban development coordination interaction [J].Journal of Shanghai economic management cadre institute.2008().pp.278-285. 